\title{
Ukrainians in Manchuria, China: A Concise Historical Survey
}

\section{Serge Cipko}

ABSTRACT: There is a body of literature that attests to Russian influence in the early development of Harbin, China, Edmonton's twin city, and northern Manchuria generally. What is not acknowledged in this literature, however, is that the "Russian" presence in Manchuria drew on considerable Ukrainian participation. This article explains why scholars of Manchuria have tended to refer to the settlers from the European parts of the Russian Empire only as "Russians" rather than distinguishing them according to their real national compartments. Then, by drawing on lirtle known sources, an examination of the background to Ukrainian settlement in the region, the evolution of the community there, and the emergence of separate Ukrainian organizarions, follows.

The study of mass European international migration at the turn of this century has overwhelmingly emphasized the transfer of emigrants to the "New World". Yet coinciding with this movement was another directed towards the "Old World". In this case, Europeans from the western regions of the Russian Empire emigrated to its recently acquired possessions in the East. In the late 19 th century and early 20 th century, geopolitical, political, and economic considerations combined to induce the Tsarist government to pursue a policy of mass colonization of the Far East. ${ }^{1}$ The process led to the Slavic enclaves established in northern Manchuria, China from the late 1890 s onwards. Northern Manchuria became the final major meeting point between the peoples of the "far east" of Europe and the peoples of the Far East of Asia. The European settlement there was to leave some profound imprints on the region's changing landscape for the next half-century.

The Ukrainian participation in the colonization of Russian-occupied territories in the Far East has received some scholarly treatment, ${ }^{2}$ though the research on this subject remains at an infant stage. The Ukrainian settlement of Manchuria, which by the second decade of this century is said to have embraced over 22,000 families, ${ }^{3}$ has been documenced even less.

Although virtually ignored, this community had an interesting and dynamic history as this paper attempts to demonstrate. That this has not been acknowledged till now can be attributed partly to their Russocentric orientation. The purpose of this article is to challenge this 
generally accepted and recurring view by presenting little-known data in a narrative form that tends to contradict rather than complement what has been published on this subject. The thesis immediately explicit here and implicit throughout the narrative is that, in reality, the Russian minority in Manchuria was not as numerous as previously stated. The Ukrainians formed a substantial proportion of those hitherto considered as "Russians", but owing to the dominant position of the local ethnic Russian group and the low national consciousness of many of the Ukrainian settlers, coupled with unfavourable conditions for Ukrainian community leaders to redress this malady, they did not evolve as an influential minority tantamount to their numbers. But notwithstanding the fact that the Ukrainian influence in Manchuria was less pronounced than the Russian, the group was significant in the region, as shall become apparent.

The Ukrainian community in Manchuria, present between the 1890 s and 1950 s, had several distinguishing features. First, the community there was situated in close proximity to the belt in the Far East known unofficially as Zelenyi klyn (The Green Wedge), which included districts in the present-day territorial divisions of the Khabarovsk and Primore krais and the Amur oblast of the Russian Federation, for a long time largely inhabited by Ukrainian colonists. ${ }^{4}$ The potential for distant regions such as this one to secede from central control was manifested during the Bolshevik Revolution and it should not come as such a surprise, given the large, compact Ukrainian settlement of Zelenyi klyn, that a group there discussed plans to create a local Ukrainian State to be known as Zelena Ukraina. ${ }^{5}$ Although this never materialized, Ukrainian political activists in Manchuria (and in Europe for that matter) remained very conscious of the large "Ukrainian reservoir" across the border. Second, Manchuria (and its largest city, Harbin, in particular) was the only region outside the USSR where Ukrainians and Russians settled alongside each other in almost equal numbers, with the exception of Paris. Third, whereas in Russian (and later, Soviet) Central Asia and Far East the Slavs were the dominant group in terms of the authority wielded, the reverse was truer in Manchuria, where the Slav population was ultimately subjected to Chinese (and later, Japanese) central control. In this context, a "compare and contrast" type of study could yield some interesting conclusions. Fourth, Ukrainians settled an area which had variously been contested by local warlords, and by the Russian (and later Soviet), Japanese, and Chinese powers - all seeking, at one time or another, to establish their dominance over the region. As the region became more densely populated, and centres such as Harbin expanded, Manchuria attracted overseas commercial interests. Harbin soon emerged to become the "Constantinople of the Far East", with 
diverse foreign consulates, enterprises, and institutions, most enjoying extra-territorial privileges, located there. Therefore, developments in Manchuria were very closely monitored by international agencies anxious to protect their vested interests there. Such was the wider context, then, but it would be beyond the scope of this article to elaborate fully on the points cited above. Each is sufficiently important to merit separate studies and is alluded to only marginally here -- that is to say, only when relevant to our objective: a concise survey of the Ukrainian experience in Manchuria.

\section{ii}

The researcher would find it difficult to locate source materials on Manchuria which deal exclusively, or in part, with the Ukrainian community. The tendency has been to confuse Ukrainians with Russians. Indeed, "Russian" has been employed as a generic term to include many of the ethnic groups of the former Russian Empire. ${ }^{6}$ Even the term "White Russian" has erroneously been applied to denote these groups. ${ }^{7}$

In those studies, where, because of their specialized nature, one would assume that greater insight into the national distinctions of the Slavic immigrants would be forthcoming, these errors are equally apparent. A case in point is the book by Amleto Vespa, Secret Agent of Japan. ${ }^{8}$ Vespa, an Italian businessman and journalist in Manchuria, who in 1932 unwillingly became an agent for the Japanese Secret Service during the Japanese occupation of the region, provides a firsthand account of Manchuria under Japanese rule. Unfortunately, Vespa, who was appointed partly because of his knowledge of "the languages and the customs of the different people living in Manchuria", is able, on occasion, to distinguish berween Russians and Poles, but fails to do so in the case of Russians and Ukrainians. D.M.B. Collier and C.L'E. Malone, in their study of Manchuria, refer to Harbin as a "very strong centre of White Russian emigrants and Ukrainians", ${ }^{10}$ but elsewhere in the study describes all Slavic immigrants in Manchuria as Russian.

Fortunately, valuable data on the Ukrainian community in Manchuria is available in the works of a former resident there, Ivan Svit (Sweet)." Born in the Kharkiv region of Ukraine, Svit settled in the Zelenyi klyn region in 1918 and from there moved to Harbin. ${ }^{12}$ In Harbin he assumed a leading role in organizing Ukrainian community life, editing newspapers, and writing extensively on Ukrainian life in Manchuria. Although Svit's studies are, in places, marred by subjectivity and tend to focus only on the political and organizational aspects of 
Ukrainian life in Manchuria, they are, nonetheless, detailed and afford us an "insider's" view of events there.

It is somewhat unfortunate that John J. Stephan, in his study of Russian fascists abroad after the Revolution, ${ }^{13}$ does not, in his section on Russian emigres in China, refer more to Svit's book on JapaneseUkrainian relations, ${ }^{14}$ where much information on Ukrainians in China is present. Stephan cites this book in his bibliography but alludes to it only once in his footnotes. In common with many of the other studies of Manchuria, Stephan downplays the numerical significance of the Ukrainian settlement of that region and consequently reinforces the myth that the European contingent in Manchuria was overwhelmingly Russian in composition.

More recently, two illuminating studies by Olga Bakich ${ }^{15}$ on early Russian influence in Harbin acknowledge, in passing, the Ukrainian presence in that city, but the regional origins of the "Russians" she discusses are not anywhere clarified. Thus, once again, one is left with the impression of a tiny Ukrainian minority dwarfed by superior Russian numbers in the vicinity. Elsewhere, though, in a review article titled "Memoirs of Harbin" by Simon Karlinsky, the provenance of the "Russian" immigrants is hinted at, suggesting that a substantial number, if not the majority, were drawn from Ukraine. Referring to the refugees who settled in Harbin after the Bolshevik Revolution, Karlinsky observes that the newcomers encountered a Slavic community whose roots were mainly in the south of the European parts of the Russian Empire. "Speakers of Russian who grew up in Harbin and later moved to the Soviet Union or the United States," he notes, "were often surprised to learn that they spoke the dialects of Kharkov or Odessa."16

This begs the question. Why have most historical studies of Manchuria neglected its former Ukrainian population? Four plausible reasons can explain this oversight. First, most of the researchers appear to have been unfamiliar with the national divisions of what was formerly the European parts of the Russian Empire and, thus, lumped all the national groups emanating from there in Manchuria into a single "Russian" whole.

Second, the language of administration, schools, institutions, and business transactions for the Slavic populations in cities such as Harbin was Russian. Even non-Slavic inhabitants learned Russian, as one former Russian resident in Manchuria, George Guins, noted: "The Russian inhabitants studied the Chinese language, while the Chinese studied Russian." 17 Therefore, Ukrainians increasingly became functionally bilingual, not in Ukrainian and Chinese, but in Russian and Chinese. Russian influence, Guin observes, extended to local government: "Russian self-government, which was established in Harbin, was 
shared by the representatives of other nationalities. However, the Russians outnumbered all of them; they were at the head of the city administration, and business affairs were conducted in Russian."18 Moreover, the names of many streets and shops were printed in Russian, and much of the architecture in northern Manchurian cities assumed Russian styles. The foreign observer was therefore correct in his/her impression that a city such as Harbin projected a Russian rather than a Russian-Ukrainian character. This view is confirmed in an official Japanese description of Harbin, which states that, "because the city was planned along the lines of Moscow, it smacks strongly of a Russian city."'19

Third, the massive influx of Russian pro-Tsarist exiles in Manchuria after the Bolshevik Revolution strengthened the concept of "one and indivisible Russia" in the region. The extreme chauvinists among them were uncompromising in their atcitude toward those among the nonRussian Slavic nationalities in Manchuria who wished to retain a separate identity. Their presence and agitation intensified the Russification of the region.

Fourth, the national consciousness of the Ukrainian immigrants, especially the majority who had settled in Manchuria prior to the Revolution, had been rather low to begin with. During the course of time, deprived of mechanisms of support for national identity retention, a very large proportion of these settlers and their offspring had become almost entirely or partially assimilated to the Russian language and culture. Many of the immigrants had learned Russian and become comfortable or accustomed to operating in the prevailing Russian environment; while their children, educated for the most part in Russian schools, by and large began to consider themselves as Russians. There would also have been cases of national dualism or dual loyalties: those who were aware that their roots and culture were Ukrainian, but who, for various reasons, chose to declare their nationality as Russian. This type of dualism may nor have been limited to this group. For instance, a census conducted in Australia in 1976 revealed that there were persons born in China who declared their nationality as Polish but their language as Ukrainian, suggesting again that the issue of identity among Manchuria's Ukrainians was a complex one ${ }^{20}$ Still, even those railway workers who chose ultimately to identify with the Russian nationality were distinguishable by the surzhyk jargon they spoke, a Ukrainian-Russian hybrid. ${ }^{21}$

Now that the complicated point of national affiliation has been outlined, we can turn to the issue of measuring the strength of Ukrainians in the area in quantitative terms as far as our sources permit. 
Ukrainian immigration into Manchuria was initially tied with the construction of the Chinese Eastern Railway (CER), a connecting link in the Trans-Siberian railway to Vladivostok. In order to save some 340 miles, it was proposed that the line run directly through Manchuria. A subsidiary company of the Russo-Chinese Bank, known as the Chinese Eastern Railway Company, was created, and in 1896 a rail contract was signed between this company and the Chinese government. Construction work began in August of 1897 and the company's administration established itself in Harbin in 1898. The CER Company did not limit itself to rail construction but also engaged in such auxiliary activities as lumbering, coal mining, navigation, and in establishing telegraph communication. By 1920, there were an estimated 150,000 citizens of the Russian Empire in the Harbin area and a further 50,000 scattered elsewhere in Manchuria. ${ }^{22}$ Among this number, as noted, were 22,000 Ukrainian families, an estimated 100,000 persons. ${ }^{23}$ As the number of permanent employees of the CER grew, the Company established a network of schools, parks, hospitals, and other social infrastructures and amenities for the settlers.

The second wave of Ukrainian immigration into Manchuria comprised an undetermined number of political refugees travelling with a larger contingent of Russian and non-Russian exiles from various parts of the Empire after the Bolshevik Revolution. Together they initially numbered upwards of 25,000, ${ }^{24}$ most of them settling in Harbin, but some eventually gravitating towards Shanghai and even further afield in Asia: to Korea, Japan, Hong Kong, Macao, Indo-China, and the Philippines. ${ }^{25}$ Smaller numbers of Ukrainians continued to arrive in Manchuria during the 1930s, either from the Soviet Far East or directly from Europe. ${ }^{26}$

The settlement of assorted political refugees in Harbin gave the city the air of Paris in the 1920s. Here converged supporters of the Ukrainian People's Republic and the monarchist Hetmanate government, diverse Russian exile groupings united only in their dissatisfaction with the new order in what was the Russian Empire, but divided on the issue of what ought to take its place, and smaller contingents of Georgians, Turkic-Tatars, Cossacks, and Siberian separatists. ${ }^{27}$ In addition, there were pro-Soviet elements among the railway workers of the CER, ${ }^{28}$ adding to the plangency of polemics between the various rival political factions.

It is impossible to determine the precise number of Ukrainians in Manchuria and to discern them from the other groups in the region emanating from territories in the former Russian Empire. Official 
statistics prior to the Japanese occupation of Manchuria in 1931 are rather vague in their enumerations, listing all Europeans under the rubric "others". From composite accounts, it appears that up to the 1920s the Ukrainian and Russian contingents, together, constituted a fairly sizable proportion of the northern Manchurian population, particularly in the city of Harbin where by the mid-1920s they continued to account for around $25 \%$ of all inhabitants. By the close of 1930 they remained a significant element in the Harbin human fabric, constituting the majority of the 69,987 "others" and sharing the city with 309,253 Chinese, 3,910 Japanese and 1,422 Koreans. ${ }^{29}$ The Chinese proportion of the Manchurian population increased substantially with economic development of the region and through abetted Chinese settlement there by the government, owing to its concern over the large presence of foreigners on its northern borders. A CER report illustrates this point:

Immediately after the Boxer Rebellion and the Russian campaign (1900), the local Manchu administration and the Chinese administration, which only at that time began to function, alarmed by the growing Russian immigration into the country and by the invasion of the same by Russian troops, resolved to consolidate their rights not only in the South, but also in North Manchuria. This could only be accomplished by effective settlement of the country by Chinese. ${ }^{30}$

The Korean community, long-established in the region, too, began to augment with direct immigration from Korea as a response to the new economic trends in Manchuria. The Japanese in Manchuria, an insignificant minority there prior to 1931 , emerged as a numerically important group from that year as the result of a deliberate colonization drive in the region. By December 31, 1934 the total Manchurian population had swollen to $32,869,054$. In addition to the Chinese majority, there were 76,429 Japanese, 662,861 Koreans and 77,545 "foreigners". Most of the "foreigners" were concentrated in the Harbin Special Municipality where they now constituted 60,133 of its 483,465 inhabitants. ${ }^{31}$

As the Chinese, Korean and Japanese share of the population rose in the 1930s, the European proportion progressively declined. However, it was the Manchu tribes, the original occupiers of the land, that were most affected by the new trends. As usually is the case when programmes of mass colonization are implemented in relatively sparsely populated areas where the indigenous peoples support a subsistence-oriented 
economy, it is these who are effectively displaced from their lands and have their conventional lifestyles interrupted.

Albeit unsatisfactory for our purposes, the Manchurian census of June 30, 1935 contains more detailed data on the ethnic divisions in the region than any of those preceding it. In this census the Japanese authorities distinguished between "Soviet" citizens, of whom there were 21,272, mainly employees on the CER, unnaturalized "White Russians", of whom there were 5,054, and 44,359 under the heading "denationalized" which embraced Russians and Ukrainians, among others. Together, these three categories formed the third largest foreign group after the Koreans $(701,161)$ and Japanese $(90,025)$. This census also revealed the presence of Poles $(1,519)$ and other smaller European groups. ${ }^{32}$ These census figures ought to be treated with caution, however. Some Ukrainians, as was the case with Russians, may have been classified as Chinese, ${ }^{33}$ and thus their real number might have been somewhat higher than the combined census total of the three categories suggests.

As the census was being conducted in June of 1935, the Ukrainian and Russian communities were undergoing a sharp decline. With the Soviet sale of the CER to Japan in 1935 the majority of Soviet citizens in Manchuria returned to the USSR, so that the number still holding Soviet citizenship in the region was reduced to 5,000 by the following year and to less than 1,000 by $1939 .{ }^{34}$ Consequently, both the Ukrainian and Russian communities together in Manchuria dwindled to 54,000 by 1940 , of which half dwelled in Harbin. ${ }^{35}$ After the departure of those Ukrainians carrying Soviet passports in the 1930s, it has been estimated that the Ukrainian community in the whole of China decreased to some 30,000 of which 15,000 lived in Harbin. ${ }^{36}$

Ivan Svit maintains that in the early 1930 s pressure was exerted on the Japanese authorities by members of the Ukrainian community in Manchuria to have Ukrainians registered as a separate nationality, not as Russians, in official documents. Apparently the pressure paid off, and Ukrainians, along with other nationality groups hitherto recorded as Russians, were given the option from 1934 of having their true ethnic origin stated on their passports. ${ }^{37}$ However, any official government data, Japanese or otherwise, which lists Ukrainians as a separate group in Manchuria, has yet to be discovered.

Thus, in the absence of official statistical data on Ukrainians, one can only speculate on such matters as the occupations and the economic integration of the Ukrainian immigrants and their descendants in 
Manchuria. On the basis of scattered references in the works of Ivan Svit and from the observations of former residents in Manchuria of Ukrainian origin now living in Australia, a picture can be formed, albeit far from complete, of the economic life of Ukrainians there. Furthermore, what has been stated of Russians in the sources consulted is generally true of Ukrainians, too.

The overwhel ming majority of Ukrainians were initially employed in railway construction. Thereafter, as the CER Company diversified its interests to include the development of the lumber industry, public works, manufacturing, mining, and agriculture, Ukrainians became engaged in maintaining these sectors. The profits the CER Company accrued from its activities were partially reinvested in developing the city of Harbin, which became a centre of supply and distribution. By 1905 the population of this city had risen to $150,000^{38}$ and continued to grow unabated, attracting native as well as foreign merchants, architects, land developers, bankers, entrepreneurs, and labour migrants from within and outside the region.

The growing population in Manchuria induced the CER Company to promote diversified agriculture in the area. Initially, the development of agriculture was in response to the consuming needs of the railway employees and soldiers stationed in Manchuria during the RussoJapanese war. ${ }^{39}$ However, the demands for foodstuffs grew still further as Manchuria became progressively densely populated, and agri-business, fostered primarily by the CER Company, gradually evolved into a thriving enterprise in the region. The development of agriculture benefited many Ukrainians who were granted land allorments along the railway. They cultivated a wide range of grains and sugarbeet, and maintained cattle ranches, poultry farms and apiaries. ${ }^{40}$ Cereals gradually became the most important export commodity of Manchuria. ${ }^{41}$

The lumber industry became another activity associated with the Ukrainian and Russian immigrants. ${ }^{42}$ Timber and lumber products, together became the second largest export commodity of Manchuria. Some Ukrainians developed successful firms in the lumber industry, for instance, the Shevchenko Brothers, who owned a forest concession at Shihtowhotze Station. The workforce in the lumber industry, though, was largely non-Slavic in origin. ${ }^{43}$

A by-product of the CER Company's operations in Manchuria was industrialization. Industrial activity was concentrated mainly in Harbin, with much of its flour mills, vodka distilleries, beer breweries, sugar refineries, furniture factories, manufacturing firms, and food processing plants, developed by Slavic settlers. The coal and iron-ore mines exploited by the CER Company in the interior provided much of the raw materials for heavy industry to be developed in the city. An ever- 
enlarging bureaucracy emerged in Harbin to manage this industrialization process.

Our sources tell us little about labour conditions among the Slavic workers. It appears that the CER Company tended to treat these workers of Slavic extraction better than its Chinese employees. For instance, lumber workers of Slavic origin received superior wage scales to their Chinese counterparts. ${ }^{44}$ According to a CER Company official report, in the manufacturing firms, "in enterprises of mixed ownership and those of purely Russian ownership, the majority of employees holding responsible positions are Russians." ${ }^{5}$ The CER Company's attitude toward labour appears to have differed considerably from that of some of the Chinese firms, as is evident from one of its statements: "The curious trait of Chinese organizations whereby employees share in the profits, in a measure counteracts the lack of regulations and makes the interest of the employer also the personal interest of the employee." 46

The speculative and competitive nature of capitalist development in Manchuria ensured that, while there was a minority that could accumulate handsome profits, there was also a great mass of people who were vulnerable to fluctuating market forces beyond their control. The position of this latter group, comprising Slavs and non-Slavs alike, was precarious, lacking job security and faced with limited options for alternative sources of livelihood, and with no access to welfare benefits to ensure survival in aleatory conditions. Such circumstances produced large-scale social banditry in the interior. Prior to 1931 there were 55,000 habitual bandits roaming the Manchurian countryside "to say nothing of the poverty-stricken people who had taken to banditry in sheer despair, unable to avoid starvation by any other means." 47 The regular bandits became known as the hunghutze because of their beards, dyed red to project a pugnacious image. The hunghutze organized an intricate network of agents and cells spanning the entire territory. Through this strategy, they were able to monitor the movements of rich merchants inside and outside the city; prey on employees and directors of the CER Company, raiding the latter's passenger and freight trains; and subject local peasant communities to tribute. ${ }^{48}$

The situation in the cities was equally insecure. In Harbin the deteriorating economic climate saw the emergence of "urban bandits", or gangs. These gangs were chiefly composed of local Slavs, driven to crime by the worsening unemployment situation. With the arrival of the post-Revolution refugees, unemployment claimed more than half the adult male Slavic population of Harbin. ${ }^{49}$ In that city, the unemployed were huddled into the Slavic ghetto of Hakhalova (dubbed "Vagabond Haunt" by some locals): "a cramped, sullen squatters' slum 
of hovels tacked together with wood scraps, paper, cloth and discarded boxes." 50 Hakhalova became a breeding ground for the formation of gangs, which patrolled the streets of Harbin at night in search of wealthy and not-so-wealthy victims. Some of these gangs were hired or manipulated by mafia types to enforce their ugly operations in the Harbin underworld, often with the tacit approval of the local authorities. ${ }^{51}$ Crime and vice became integrated features of the economic and social fabric of Harbin. The city evolved as fertile territory for the diffusion of contraband, trafficking in narcotics (opium in particular), gambling and prostitution. The Japanese occupiers from 1931 onwards did little to regulate vice and in some cases even fostered its development: "the seediest elements soon infested Manchuria as proprietors of gambling houses, brothels, and opium dens." 52 Indeed, the vice prevalent in Harbin in the 1930s earned the city a reputation that rivalled Havana at the time.

However bad conditions were getting for Slavic males in Manchuria, the situation was worse still for their female counterparts. A minority of women were fortunate to secure jobs as school teachers and in the civil service. Some worked in sectors such as the textile industry, where they added a new dimension in the cloths and blankets they worked by embroidering in them Slavic patterns. ${ }^{53}$ Still others were employed in various service and domestic categories. But many women were either housewives or employed in the tertiary/informal sector: as street vendors -- retailing flowers, trinkers, newspapers or such delicacies as perogies $^{54}$-- and, as may have been more the case, in prostitution.

If there is a solitary unifying theme in most of the sources consulted dealing with Manchuria in the 1930s, it is the consensus that prostitution there was rife during that decade, among the Slavic women in particular. As one contemporary observer recounted: "The problem of prostitution among women is a terrible one, and Russian women the greatest sufferers". ${ }^{55}$ Prostitution paid little attention to age: "Little girls in cotton print dresses could be seen offering themselves at hourly rates." ${ }^{66}$ Such was the social breakdown in Manchuria that the effect had some grave demographic repercussions on its Slavic population. For this group, the mortality rate exceeded the birth by a ratio of 2:1, "thanks to abortions, assaults and alcohol." 57

Therefore, there was no uniformity in the pattern of integration into the economic structure of Manchuria for Ukrainians. In 1934 the Japanese authorities created in Manchuria the official central representative body, Bureau for Russian Emigrant Affairs (BREM). Among orher things, BREM was charged with gathering detailed data on all "Russians" living in Manchuria except Soviet citizens. But BREM's supervision encompassed more than just ethnic Russians; "BREM 
wielded jurisdiction not only over ethnic Russians but over nationalities who had lived within the old Russian Empire: Ukrainians, Poles, Estonians, Latvians, Lithuanians, Georgians, Armenians, Tartars, and Baltic Germans." ${ }^{8}$ All these groups were de facto compelled to register with BREM, for not to do so would solicit the suspicion of the authorities and deprive the offenders of certain civil rights. ${ }^{59}$

In November of 1935 BREM conducted an official survey of the occupational structure of all its registrants above the age of 17 . Some 22,526 persons were tested. It was revealed that 12,275 of these were unemployed. Of those who were classified as gainfully employed, 712 were railway employees, 1,968 were engaged in business and industry, and 7,571 were categorized as labourers. It was found that these labourer registrants were earning a similar wage to their Chinese counterparts, but were paid less than Japanese labourers. ${ }^{60}$ The Japanese authorities did introduce measures to improve the deteriorating lot of the Slavic population in Manchuria, but these had little lasting effect and in general standards of living continued to fall. This fact served as a source of resentment on the part of the Slavic minorities toward the Japanese regime and particularly disillusioned those who had been initially optimistic that the new Japanese order would prove to be an improvement over the previous Chinese one. ${ }^{61}$

v

The evolution of organizational life among Ukrainians in Manchuria can loosely fall into three periods: 1903-1916, when Ukrainian organizations were tied to the CER Company; 1917-1930, when organizations with a definite Ukrainian character emerged independently, but whose activities were curtailed owing to a negative attitude towards them by the local Chinese administration and by Russian ultranationalists; and 1931-1945, from the Japanese occupation of Manchuria in September of 1931 (and the subsequent establishment of the Manchoukuo buffer state in February of 1932, which comprised all of the territory of Manchuria and from 1933 a little more besides) to the Soviet invasion in the summer of 1945. During this last period Ukrainian organizational life experienced a brief revival, but steadily declined from the mid-1930s onwards, owing to a change in Japanese policy and then terminated altogether when the Soviets arrived.

Little is known about the early Ukrainian organizations. It appears the first known Ukrainian cultural society was established in Liao-Yang, in southern Manchuria, in 1903. ${ }^{62}$ Ukrainians formed various amateur and professional drama troupes within the railway workers' clubs. After the 1905 Revolution a Ukrainian Hromada (Community) Society was 
formed in Shanghai (1906) from Ukrainian migrants formerly in Manchuria, and a year later a Ukrainian Club was created in Harbin. ${ }^{63}$ The Ukrainian Club, renamed the Ukrainian People's Home in 1918, became the backbone of organized Ukrainian life in northern Manchuria throughout the period of Ukrainian settlement in the region.

The drive for independence in Ukraine in 1917-1921 stimulated intense organizational activity among Ukrainians in Manchuria. Several organizations were founded and affiliated with a coordinating board, the Manchurian District Council, which was set up in 1917 in Harbin and, till its expiry in 1921, embraced nine different Ukrainian communities in Manchuria. ${ }^{64}$ This Council maintained strong ties with the Ukrainian settlements in the Russian Far East and also with Ukraine, itself. A consulate of the Ukrainian People's Republic (UPR) was established in Harbin and a military unit formed there was duly dispatched to Ukraine to assist the UPR's war efforts. ${ }^{65}$

After the Bolsheviks assumed control of the Russian Far East, the links between Ukrainians there and the Ukrainian organizations in Manchuria were terminated. After the Bolshevik Revolution, the leadership of many of the existing Ukrainian organizations in Harbin was taken over by political refugees from the Far East, who imbued in them a new direction. Most of these political refugees were supporters of the UPR, the short-lived democratic independent Ukrainian state, which had an uneasy and intermittent existence in 1918-1921, and, thus, were anti-Soviet. A small minority, known as the "Hetmanites", were sympathetic to Hetman Pavlo Skoropadsky, who briefly established a monarchy in Ukraine, with the help of German forces in 1918, which the UPR subsequently overthrew.

The group associared with the Ukrainian People's Home, its leadership now dominated by UPR sympathizers, had to contend with many factions hostile to it. On the one hand there was the local Chinese administration, which at first took an ambivalent attitude towards its activities but eventually, partly in response to the demands of local Russian circles and partly due to the rise of Chinese nationalism, repressed most Ukrainian organizations altogether ${ }^{66}$ On the other hand, there was the chauvinist attitude of certain Russian political factions, some of which would tolerate Ukrainian organizations only if these published their press and conducted their affairs in the Russian language. ${ }^{67}$ Polemics between the Ukrainian press in Manchuria and the press of these Russian circles were carried out throughout the period of the setclement of both groups there and added to the cohesion of the patently threatened Ukrainian minority associated with the Ukrainian People's Home ${ }^{68}$ Finally, the latter received opposition from within the Ukrainian community in Manchuria, itself. Friction occurred between 


\section{Past Imperfect}

the "old" and the "new" immigrants over the purpose of Ukrainian organizational life in Manchuria. Many of the old immigrants resented the sharp political tone of activities conducted by the refugees and preferred the stress to be placed on cultural issues and on matters directly concerned with the welfare of the community in Manchuria. ${ }^{69}$

With the Japanese occupation of Manchuria from 1931, the Ukrainian community was permitted to revive their banned organizations. A number of new associations, catering to youth, pedagogical, and publishing concerns, were set up, and, from December 1932, a Ukrainian-language weekly, Mandzhurskyi vistnyk was founded. ${ }^{70}$ Some charitable work in the mainstream society was also conducted..$^{71}$

But although Ukrainian organizations began to flourish from 1931 onwards, they did so amidst provocations. Ukrainian community leaders would periodically file complaints with the Japanese authorities that elements hostile to their activities were employed in the local police force and in BREM. These employees would abuse their positions to bring forth unwarranted investigations of community affairs. One such incident concerned the anniversary of the declaration of Ukrainian national independence, celebrated every year on January 22 by the Ukrainian People's Home. On one occasion it had been claimed to the Japanese Military Mission that these commemorations were actually a cover with which to mark the anniversaries of Lenin's death (January 21,1924 ) and of Bloody Sunday (January 22, 1905)..$^{72}$

The year 1935 marked the peak of Ukrainian activity. In January an umbrella body, the Ukrainian National Colony, was created as the legal representative entity for all Ukrainians in Manchuria. It planned a Far Eastern Conference which aimed to include Ukrainian representatives from China proper, but this objective proved to be unfeasible owing to tense relations between Japan and China. Nonetheless, the Conference went ahead, albeit limited to delegates of Ukrainian organizations in Manchuria. ${ }^{73}$

However, by late 1935, owing to the outbreak of war between China and Japan, the deteriorating relations with the Soviet Union, and influenced by events in Italy and Germany, Japanese policy towards Ukrainians entered a new, repressive phase "in which the Ukrainian question had no place."74 The Japanese now supported only those groups that they considered unquestionably politically reliable. In response to the changing environment in Manchuria, several Ukrainian community leaders moved on to Shanghai, where there were fewer restrictions. The decline of Ukrainian organizational activity in Manchuria culminated when the Soviets invaded the region in August of 1945. 
The Ukrainian community had barely taken root in Manchuria before it was on the move again. Ukrainians in Manchuria first began to migrate southward within China to such places as Tianjin (near the Chinese capital of Beijing) and Shanghai, and, by the 1900s, in large numbers, they started to emigrate overseas, especially to Australia and Hawaii. ${ }^{75}$ After World War I, Canada entered the Manchurian connection when some 625 individuals from the Harbin area were assisted by assorted Canadian agencies, including the Ukrainian Immigration and Colonization Association based in Edmonton, to settle in Alberta in the $1920 s^{76}$

However, by far the largest exodus of Ukrainians from Manchuria occurred in the 1940s. The progressive movement of Ukrainians to Shanghai had already begun in the 1900 s, but, from the 1930 s to the late 1940s, this movement had accelerated. When the Soviets arrived in Manchuria in 1945 random arrests and deportations of the Slavic inhabitants took place, ${ }^{77}$ accompanied by an intensive campaign urging the settlers and their descendants to apply for Soviet citizenship and return to the USSR (this campaign was also extended to Shanghai). ${ }^{78}$ Coerced and uncoerced repatriation was partially successful; about half the Slavic population resettled in the USSR. ${ }^{79}$ From the mid-1940s Shanghai superseded Harbin as the centre of Ukrainian cultural and political life. Those Ukrainians still remaining in Manchuria steadily gravitated toward Shanghai and, from there, moved overseas, either at their own expense or with the assistance of various relief and welfare agencies, including Ukrainian ones based in the Americas. By the late 1960s the Ukrainian community in China had been reduced to a negligible number, ${ }^{80}$ the overwhelming majority now having been either repatriated to the USSR or resettled among the Ukrainian communities in the diaspora.

What vestiges have the Ukrainians left behind in Manchuria? Aside from the fact that a case can be made that they assisted in laying the foundations for diversified agriculture, industrialization, and cultural pluralism in northern Manchuria; Ukrainian cuisine, which is still in demand in Harbin, ${ }^{81}$ and the Ukrainian Orthodox Church of the Holy Protectress in the same city, which is still in use serving a local community of worshippers, bear testimony to a heritage that has not altogether been abandoned. 


\section{NOTES}

The author wishes to acknowledge the contribution in the research of this article of Nonna Ryan, a Tutor in Russian with the School of Modern Languages at Macquarie University and a former Harbinite.

' See the entry on the "Far East" by V. Kubijouye and Ivan Svit in Encyclopedia of Ukraine, $1984 \mathrm{ed}$. Still useful is the study by Walter Kolarz, The Peoples of the Far East (New York, 1954).

2See the entry on "Zelenyi klyn", by V. Kubijouye and Ivan Svit, particularly the bibliography at the end, in Entsyklopediia ukrainoznavstva.

${ }^{3}$ Ivan Svit, "Ukrainsko-Iaponski vzaiemyny," Vyzvolnyi shliakh(London) no.11/ 12 (1967), 1276

${ }^{4}$ See note 2 .

${ }^{5}$ Ibid.

"See, for instance, S.V. Vostrotin, "A Russian View of Manchuria," The Slavonic and East European Review 2 (1932-33), 20-26; George Guins, "Russians in Manchuria," The Russian Review 2:2 (1943), 81-87.

7 See, for instance, F.C. Jones, Manchuria Since 1931 (London, 1949).

${ }^{8}$ Amleto Vespa, Secret Agent of Japan: A Handbook to Japanese Imperialism (London, 1938)

${ }^{9}$ Ibid., 49

${ }^{10}$ D.M.B. Collier and C.L'E. Malone, Manchoukuo: Jewel of Asia (London, 1936), 145

"Some of his works are cited below. In addition, the reader is referred to his useful survey of the Ukrainian People's (National) Home, Ukrainskyi Natsionalnyi Dim $v$ Kharbini (Odessa-Harbin, 1943).

${ }^{12}$ See the entry on "Ivan Svit" in Entsyklopedia ukrainoznavtsva, 1973 ed. In 1951 Svit resettled in the USA.

${ }^{13}$ John J. Stephan, The Russian Fascists: Tragedy and Farce in Exile, 1925-1945 (London, 1978)

${ }^{14}$ Ivan Svit, Ukrainsko-Iaponski vzaiemyny, 1903-1945 (New York, 1972)

${ }^{15}$ Olga Bakich, "Origins of the Russian Community on the Chinese Eastern Railway," Canadian Slavonic Papers 27:1 (March 1985), 1-14; Olga Bakich "A Russian City in Harbin Before 1917," Canadian Slavonic Papers 28:2(June 1986), 129-148

${ }^{16}$ Simon Karlinsky, "Memoirs of Harbin," Slavic Review 48:2(1989), 285

17 Guins, "Russians in Manchuria," 82

${ }^{18}$ Ibid. See also Chinese Eastern Railroad Company, North Manchuria and the Chinese Eastern Railway (New York-London, 1982), 41-43. This is a reprint of the original, first published in 1924 in Harbin.

${ }^{19}$ Japan, Japan-Manchoukuo Year Book for 1939 (Tokyo, 1939), 869

${ }^{20}$ Charles A. Price, "The Demography of Polish Setrlers in Australia," in Polish People and Culture in Australia, eds. Ronald Sussex and Jerzy Zubrzycki (Canberra, 1985), 39 
2) Iurii Tkach, Resource: Materials on Ukrainians in Australia (Doncaster, Vic., Australia, 1982), 5

${ }^{22}$ The Modern Encyclopedia of Russian and Soviet History, 1978 ed., "Chinese Eastern Railway," by Edward Glatfelter

${ }^{23}$ Ukrainskyi emigrant ([Lviv, Ukraine] 15 February, 1929, 4) reported that "several years ago" the Manchurian District Council based in Harbin conducted a census of Ukrainians living in Manchuria and arrived at the figure of 100,000. ${ }^{24}$ Canfield F. Smith, Vladivostok Under Red and White Rule: Revolution and Counterrevolution in the Russian Far East, 1920-1922 (Seattle and London, 1975), 75 . On page $206 \mathrm{n} 20$ Smith states that orher estimates put the figure as high as 57,000 .

${ }^{25}$ Ben Dorfman, "White Russians in the Far East," Asia, March 1935, 167

26 See, for instance, Svit in Vyzvolnyi shliakh no.3 (1968), 357. For the extraordinary story of one couple's exit to Manchuria, see Down Memory Trails: A History of Two Hills and Surrounding Area (Two Hills, Alberta, 1986), 620-621. ${ }^{27}$ On the Siberian separatists, see S. Postnikov, "Separatist tendencies among the Russian Emigres," The Slavonic and East European Review 17 (1938-39), 358359.

${ }^{28}$ Great Soviet Encyclopedia, 1978 ed., "Harbin"; Jones, Manchuria Since 1931, 76-77

${ }^{29}$ East-Asiatic Economic Investigation Bureau, Manchuria Year Book (Tokyo, 1931), 7

${ }^{30}$ CER Company, North Manchuria and the Chinese Eastern Railway, 8

31 The South Manchuria Railway Company, Eighth Report on Progress in Manchuria (Dairen, 1936), 151

32 Japan, Japan-Manchoukuo Year Book for 1936 (Tokyo, 1936), 656

${ }^{33}$ Dorfman, "White Russians in the Far East," 167

${ }^{34}$ Stephan, Russian Fascists, 176; Svit, Vyzvolnyi shliakh no.3 (1968), 357

${ }^{35}$ Guins, "Russians in Manchuria," 81

${ }^{36}$ Encyclopedia of Ukraine I, 454

${ }^{37}$ Svit, Vyzvolnyi shliakh no.1 (1968), 49-50

${ }^{38}$ CER Company, North Manchuria and the Chinese Eastern Railway, 271

${ }^{39}$ Ibid., 73

${ }^{10}$ Nonna Ryan, "Ukrainian Immigration to the Far East," (Unpublished paper,

Ukrainian Studies Centre, Macquarie University, Sydney), 9

${ }^{41}$ CER Company, North Manchuria and the Chinese Eastern Railway, 285; Jones, Manchuria Since 1931, 7

${ }^{42}$ Collier and Malone, Manchoukuo, 96

${ }^{43}$ CER Company, North Manchuria and the Chinese Eastern Railway, 179, 190

${ }^{14}$ Ibid., 192

${ }^{45}$ Ibid., 228

46 Ibid., 229

${ }^{17}$ Collier and Malone, Manchoukuo, 109

${ }^{48}$ Stephan, Russian Fascists, 46 
${ }^{49}$ Ibid., 47

${ }^{50}$ Ibid., 42

${ }^{51}$ Vespa, Secret Agent of Japan; Stephan, Russian Fascists

${ }^{52}$ Ibid., 78; see also Vespa, Secret Agent of Japan. For a contemporary journalistic account of conditions in Manchoukuo, see Edgar Snow, "Japan Builds a New Colony," Saturday Evening Post February 24, 1934, 12-13, 80-87.

${ }^{53}$ Collier and Malone, Manchoukuo, 213

${ }^{54}$ Down Memory Trails, 621

${ }^{55}$ Collier and Malone, Manchoukuo, 116. See also Dorfman, "White Russians in the Far East," 169; Vespa, Secret Agent of Japan

s6 Stephan, Russian Fascists, 47

57 Ibid., 46

${ }^{58}$ Ibid., 176

${ }^{59}$ Guins, "Russians in Manchuria," 84-85

${ }^{60}$ Jones, Manchuria Since 1931, 79

${ }^{61}$ Dorfman, "White Russians in the Far East," 170. For a view representing the expectations of a segment of the business community in Manchuria, see Vostrotin, "A Russian View of Manchuria," 32-35.

${ }^{62}$ Ukraine: A Concise Encyclopedia, 1971 ed., "China," by Ivan Svit

${ }^{63}$ Svit, Vyzvolnyi shliakh no.9 (1967), 1038

${ }^{64}$ Entsyklopedia ukrainoznavstva 2/4, 1460

${ }^{65}$ Ivan Svit, "Ukrainskyi konsuliat v Kharbini," in Kalendar 'Svobodu' na zvychainyi rik 1957, Ukrainian National Association yearbook (Jersey City, 1957), 127-132

${ }^{66}$ Mykhailo Marunchak, Ukraintsi v SSSR poza kordonamy URSR (Winnipeg, 1974), 162-163

${ }^{67}$ Ivan Svit states: "It is necessary to emphasize that Harbin from 1918 became an important centre of reactionary Muscovite activists and their organizations, which endeavoured in their utmost to undermine the activities of Ukrainians and their organizations" (Vyzvolnyi shliakhno.7/8 [1967], 875). See also the Lviv daily Dilo, 5 March 1935, 4.

${ }^{68}$ Svit, Vyzvolnyi shliakh no.7/8 (1967), 867

${ }^{69}$ Svit, Vyzvolnyi shliakh no.11/12 (1967), 1276, 1287-88; no.3 (1968), 358

${ }^{70}$ For a list of periodicals in China with a Ukrainian content see Oleksander Malytsky, "Ukrainski tematychno u periodychni vydannia v Kytai," Journal of Ukrainian Studies (Edmonton) 12:2(Winter 1987), 92-94. The publishing activities of Ukrainians in Manchuria were also reported in Dilo 6 November 1935, 4.

71 "Natsionalnye gruppy v Kharbine," in Iubileinye sbornik Politekbnik, S.I.Z. (Russian emigre yearbook) (Sydney, 1979), 240

${ }^{72}$ Svit, Vyzvolnyi shlaikh no.4 (1968), 499

73 Svit, Vyzvolnyi shliakh no.3 (1968), 358-59; 'V Tientzyni,' Dalekyi skhid (Harbin) no.2, 10 June, 1938, 31 
${ }^{74}$ Svit, Vyzvolnyi shliakh no.7/8 (1968), 913

${ }^{75}$ Peter Krawchuk, "Ukrainians in Australia," The Ukrainian Canadian, November 1981, 14-16; Michael Ewanchuk, Hawaiian Ordeal: Ukrainian Contract Workers 1997-1910 (Winnipeg, 1986), 78-146

${ }^{76} \mathrm{~A}$. Balawyder, "Russian Refugees from Constantinople and Harbin, Manchuria enter Canada (1923-1926)," Canadian Slavonic Papers 14 (1972), 24-29; Myron Gulka-Tiechko, "Interwar Ukrainian Immigration to Canada 1919-1939" (MA thesis, University of Manicoba, April 1983), 165-173

${ }^{77}$ For a view of the Soviet occupation of Manchuria and the treatment of the Slavic population, see I.S. Ilin, "Sovetskaia Armia v Kharbine," Novyi zhurnal 96 (1969), 130-152.

${ }^{78}$ Anatole Konovets, "The Role and Function of Conflicts in the Life of the Russian Community in Sudney" (BA thesis, University of New Sourh Wales, 1968), 34, 54

${ }^{79}$ Stephan, Russian Fascists, 367

80 Petro Potichny, "Kytai u 1986 rotsi: vrazhennia z podoroshi," Vidnova (Philadelphia) 6/7 (1987), 348; Victor Petrov, Gorod na Sanguri (Washington, 1983), 82; Stephan, Russian Fascists, 367; Remi Alley, Travels in China 19661971 (Peking, 1973), 391

${ }^{81}$ Stephan, Russian Fascists, 367 